\title{
Laryngocele: Diagnostic to Treatment
}

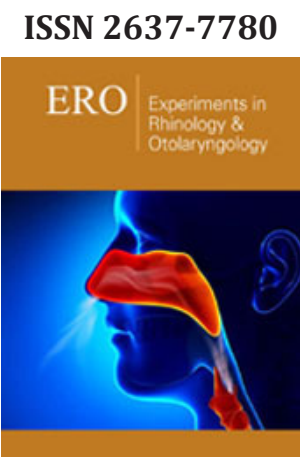

*Corresponding author: Fatogoma Issa Kone, Assistant Professor, Department of Surgery, ENT Head and Neck surgeon, Bamako, Mali

Submission: 海 January 2, 2020

Published: 偨January 21, 2020

Volume 3 - Issue 2

How to cite this article: Fatogoma I, Naouma C, Nfaly K, Kassim D, Kalifa $\mathrm{C}$, et al. Laryngocele: Diagnostic to Treatment. Exp Rhinol Otolaryngol 3(2). ERO.000556.2020.

DOI: 10.31031/ERO.2020.03.000556

Copyright@ Fatogoma Issa Kone, This article is distributed under the terms of the Creative Commons Attribution 4.0 International License, which permits unrestricted use and redistribution provided that the original author and source are credited.

\author{
Naouma Cissé ${ }^{1}$, Fatogoma Issa Kone ${ }^{1 *}$, Kadidiatou Singare ${ }^{1}$, Nfaly Konate ${ }^{1}$, \\ Kassim Diarra ${ }^{1}$, Kalifa Coulibaly ${ }^{1}$, Sidiki Dao ${ }^{2}$, Dienta Lassina ${ }^{3}$, Siaka \\ Soumaoro ${ }^{1}$, Boubacary Guindo ${ }^{1}$, Samba Karim Timbo ${ }^{1}$ and Moahamed \\ Amadou Keita ${ }^{1}$ \\ ${ }^{1}$ Department of surgery, ENT Head and Neck surgery, Mali \\ ${ }^{2}$ Health reference center IV, ENT Head and Neck Surgery, Mali \\ ${ }^{3}$ ENT -Head Neck surgery, Hospital Regional of Mopti, Mali
}

\begin{abstract}
Objectives: Discuss the antipathogenic, diagnostic and therapeutic aspect.

Case report: These are two female patients of 30-day, 35-year-old who received mass consultation for the left mandible. The cervical mass in both cases were expansive respectively to screaming and maneuvering Valsalva. Healing of the pathway associated with dyspnea was found in the first and dysphonia in the second. Nasofibroscopy revealed left ventricular tumefaction with both patients. Pharyngolaryngeal CT scan has confirmed laryngocele. The treatment was surgical with excision of the pocket in the second patient and in the first patient the surgical alternative could not be performed.
\end{abstract}

Conclusion: Laryngocele is a rare dilatation of the laryngeal saccule. The clinical characteristics are orientative elements. The pharyngolaryngeal CT scan is a reliable diagnostic tool. The surgical excision of the laryngocele is the gold standard and compensates for recurrence

Keywords: Laryngocele; Swelling cervical; CT Scan-Surgical Excision

\section{Introduction}

Laryngocele is a hernia or dilatation of the saccule of the laryngeal appendage [1-4]. It was first described in 1829 by Larrey Napoleon's surgeon during the Egyptian campaign among the muezzins calling the faithful from the top of the minarets [2,3]. In 1967 Virchow introduced the term laryngocele [2,3]. It represents a 1 case for 2.5 million inhabitants [2]. Its etiopathogenesis is unknown, the congenital and acquired hypothesis are admitted $[1,5]$. Laryngocele can be asymptomatic and incidental discovery. Its clinical spectrum may be unobtrusive or may be marked by signs of compression and/or laryngeal obstruction: cough, dyspnea, dysphonia, dysphagia, or expansive laterocervical swelling in the Valsalva maneuver $[1,6]$. It enters a clinical confrontation with the masses of the cervical region. The pharyngolaryngeal computed tomography allows removing the diagnostic doubt. It can be supported by resonance imaging and cervical ultrasound [1]. The treatment of choice is surgery externally with thyrotomy and excision of the laryngocele pocket [1]. With the advent of the miniinvasive pathway by endoscopic treatment the care has been revolutionized in terms of evolution in decreasing of the postoperative morbidity. We reported two cases of laryngocele by discussing the antipathogenic, diagnostic and therapeutic aspect and a review of the literature $[7,8]$.

\section{Observation}

\section{Case report 1}

Patient aged 30 days admitted for mass under the angle of the left mandible Figure 1 and a hoarseness of the voice appeared to 15 days of the birth. These symptoms have been associated with stage 2 inspirational dyspnea, according to Chevalier Jackson and Pineau. Prenatal surveillance was unremarkable and eutocic delivery occurred. The patient was afebrile. The mass was painless, mobile, non-expansive with cough and not depressible on palpation. It measured about $7 \mathrm{~cm}$ in its large diameter. Nasofibroscopy found a swelling of the left ventricular band with mass effect on the ipsilateral vocal cord. The pharyngolaryngeal 
computed tomography showed a circumscribed mass of aerial density, sitting at the level of the paraglottic region extending to the region from the angle of the left mandible. The anatomopathological result of the various operative specimens concluded that a pseudotirified epithelium ciliated with goblet cells without signs of malignancy. The diagnosis of left mixed laryngocele was established. The surgical treatment could not be performed because refused by the parents and the patient benefited from recurrent traditional exsufflation punctures of the mass.

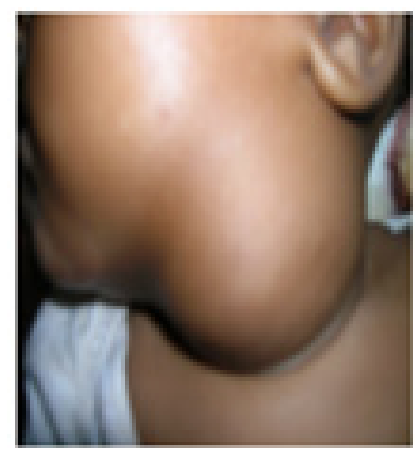

Figure 1: Observation 1 Mass from the angle of the left mandible.

\section{Case report 2}

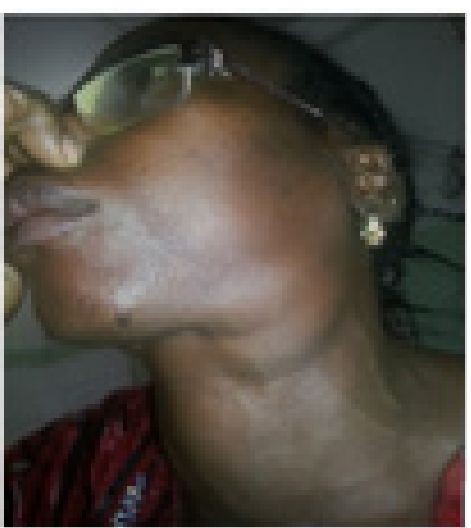

Figure 2: Observation 2: Expansive mass at the Valsalva manouvre.

Patient 35 years old housewife admitted for mass under the angle of the left mandible found since birth. The mass has evolved in an intermittent mode with an increase in volume since about 1 year, associated with permanent dysphonia. No antecedents were noted. The mass measured about $10 \mathrm{~cm}$, was expansive to the Valsalva maneuver Figure 2, depressible and hinting a 'Bryce' sound. Nasofibroscopy revealed tumefaction of the left ventricular band. The pharyngolaryngeal computed tomography showed a circumscribed mass of air density, sitting at the level of the paraglottic region extending to the region from the angle of the left mandible Figure 3. A "J" cervical approach of Paul Andre was performed with a dissection from the laryngocele pocket to the thyrohyodial membrane Figure 4. After locating and dissecting the superior laryngeal pedicle we proceeded to ligation and section of the laryngocele at its inlet without lateral thyrotomy. The outcome was simple with release of the patient on postoperative day 2 . Anatomo-pathological examination of the operative specimen Figure 5 found a respiratory-type mucosa with a pseudostratified epithelium with hair cells and goblet cells without signs of malignancy Table 1.

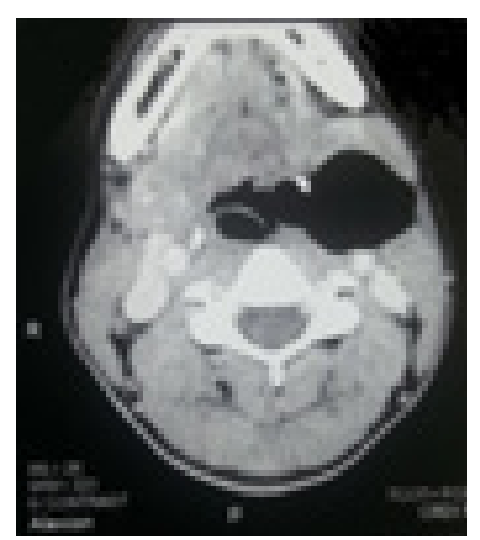

Figure 3: Observation 2: pharyngolaryngeal CT showing a mixed left laryngocele.

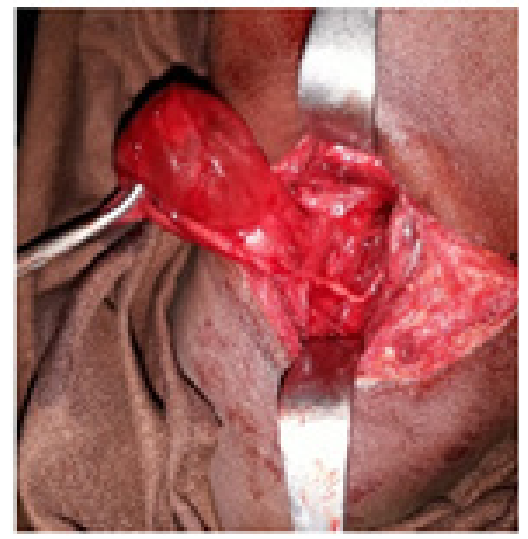

Figure 4: Observation 2: Perioperative laryngocele pocket.

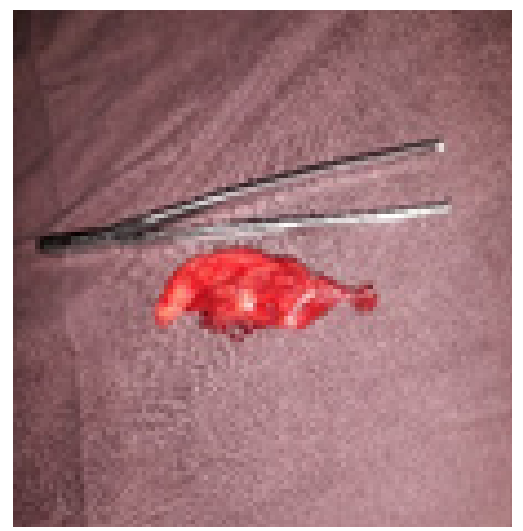

Figure 5: Observation 2: Operative part. 
Table 1: Aspect demographic-diagnostic and treatment of patients.

\begin{tabular}{|c|c|c|c|c|c|c|c|c|c|c|c|c|}
\hline \multirow[b]{2}{*}{ Authors / Year } & \multirow{2}{*}{$\begin{array}{l}\text { Number } \\
\text { of Cases }\end{array}$} & \multirow{2}{*}{$\begin{array}{l}\text { Age } \\
\text { (Year) }\end{array}$} & \multirow[t]{2}{*}{ Risk Factors } & \multicolumn{3}{|c|}{ Functional Signs } & \multicolumn{3}{|c|}{$\begin{array}{l}\text { Characteristics of Swel- } \\
\text { ling }\end{array}$} & \multicolumn{2}{|c|}{ Lanryngocele Type } & \multirow[t]{2}{*}{ Treatment } \\
\hline & & & & Dyspnea & $\begin{array}{l}\text { Dyspho- } \\
\text { nia }\end{array}$ & $\begin{array}{l}\text { Dyspha- } \\
\text { gia }\end{array}$ & $\begin{array}{l}\text { Expan- } \\
\text { sible }\end{array}$ & $\begin{array}{l}\text { De- } \\
\text { pres- } \\
\text { sible }\end{array}$ & $\begin{array}{l}\text { Bryce } \\
\text { sign }\end{array}$ & Bilateral & Unilateral & \\
\hline Kara et al. [1] & 1 & 70 & no risk factor & Yes & Yes & Yes & - & Yes & - & External & & $\begin{array}{l}\text { external } \\
\text { surgery }\end{array}$ \\
\hline \multirow{2}{*}{$\begin{array}{l}\text { Swain KS et } \\
\text { al. [2] }\end{array}$} & \multirow{2}{*}{6} & \multirow{2}{*}{$45-70$} & $\begin{array}{l}\text { (3) professional } \\
\text { voice }\end{array}$ & \multirow{2}{*}{ No } & \multirow{2}{*}{ Yes } & \multirow{2}{*}{ No } & \multirow{2}{*}{ Yes } & \multirow{2}{*}{ Yes } & \multirow{2}{*}{-} & & \multirow{2}{*}{ External } & \multirow{2}{*}{$\begin{array}{l}\text { external } \\
\text { surgery }\end{array}$} \\
\hline & & & $\begin{array}{l}\text { (1) professional- } \\
\text { wind instrument }\end{array}$ & & & & & & & & & \\
\hline $\begin{array}{c}\text { Gupta SC et al. } \\
{[3]}\end{array}$ & 1 & 35 & - & No & No & No & Yes & Yes & - & & External & $\begin{array}{l}\text { external } \\
\text { surgery }\end{array}$ \\
\hline $\begin{array}{l}\text { Oukessou Y et } \\
\text { al. [4] }\end{array}$ & 1 & 65 & $\begin{array}{c}\text { Construction } \\
\text { worker }\end{array}$ & Yes & Yes & No & Yes & Yes & - & & External & $\begin{array}{l}\text { external } \\
\text { surgery }\end{array}$ \\
\hline $\begin{array}{l}\text { Zagkou E et } \\
\text { al. [5] }\end{array}$ & 1 & 46 & $\begin{array}{l}\text { Carcinome } \\
\text { laryngée }\end{array}$ & No & No & No & No & No & - & & Internal & $\begin{array}{l}\text { external } \\
\text { surgery }\end{array}$ \\
\hline Felix JA et al. [6] & 1 & 45 & no risk factor & Yes & Yes & No & - & - & - & & External & $\begin{array}{l}\text { external } \\
\text { surgery }\end{array}$ \\
\hline Aslaner MA [13] & 1 & 28 & no risk factor & No & No & No & Yes & - & - & - & External & $\begin{array}{l}\text { external } \\
\text { surgery }\end{array}$ \\
\hline $\begin{array}{l}\text { Mohamed I. T et } \\
\text { al. [14] }\end{array}$ & 1 & 17 & no risk factor & No & No & No & No & No & - & & External & $\begin{array}{l}\text { external } \\
\text { surgery }\end{array}$ \\
\hline \multirow{2}{*}{$\begin{array}{l}\text { Kishore CP et } \\
\text { al. [7] }\end{array}$} & \multirow[b]{2}{*}{5} & \multirow[b]{2}{*}{$16-78$} & $\begin{array}{l}\text { (2) manual } \\
\text { worker }\end{array}$ & \multirow[b]{2}{*}{ No } & \multirow[b]{2}{*}{ Yes } & \multirow[b]{2}{*}{ No } & \multirow[b]{2}{*}{ Yes } & \multirow[b]{2}{*}{ Yes } & \multirow[b]{2}{*}{ - } & \multirow[b]{2}{*}{ External } & & \multirow{2}{*}{$\begin{array}{l}\text { No treat- } \\
\text { ment and } \\
\text { external } \\
\text { surgery }\end{array}$} \\
\hline & & & $\begin{array}{l}\text { (1) professional } \\
\text { wind instrument }\end{array}$ & & & & & & & & & \\
\hline $\begin{array}{c}\text { Lam SY Lau HY } \\
{[8]}\end{array}$ & 1 & 75 & ВPCO & Yes & No & Yes & - & - & - & & Mixte & $\begin{array}{l}\text { Endoscopie } \\
\text { laser CO2 }\end{array}$ \\
\hline $\begin{array}{l}\text { Mobashir MK et } \\
\text { al. [9] }\end{array}$ & 11 & $36-64$ & - & No & Yes & No & - & - & - & & $\begin{array}{l}\text { Internaland } \\
\text { external }\end{array}$ & $\begin{array}{l}\text { Endoscopie } \\
\text { laser CO2 et } \\
\text { voie externe }\end{array}$ \\
\hline $\begin{array}{l}\text { M Vishnu Vard- } \\
\text { han Reddy et al. } \\
{[10]}\end{array}$ & 1 & 35 & no risk factor & No & Yes & No & Yes & Yes & - & & $\begin{array}{c}\text { Internal } \\
\text { and exter- } \\
\text { nal }\end{array}$ & $\begin{array}{l}\text { Endosco- } \\
\text { pie et voie } \\
\text { externe }\end{array}$ \\
\hline $\begin{array}{c}\text { Tahwinder U et } \\
\text { al. [11] }\end{array}$ & 1 & 77 & polio at 10 years & No & Yes & No & Non & - & - & & Internal & Endoscopie \\
\hline $\begin{array}{c}\text { Ronald JE et al. } \\
\text { [12] }\end{array}$ & 2 & $65-68$ & (1) $\mathrm{BPCO}$ & Yes & - & - & Yes & - & - & & $\begin{array}{c}\text { Internal } \\
\text { and exter- } \\
\text { nal }\end{array}$ & $\begin{array}{l}\text { external } \\
\text { surgery }\end{array}$ \\
\hline $\begin{array}{c}\text { Rachid M et al. } \\
\text { [17] }\end{array}$ & 1 & 45 & no risk factor & No & No & Yes & - & - & - & & External & $\begin{array}{l}\text { external } \\
\text { surgery }\end{array}$ \\
\hline $\begin{array}{c}\text { Ciabatti P G et } \\
\text { al. [19] }\end{array}$ & 1 & 69 & - & No & Yes & Yes & Yes & Yes & - & & $\begin{array}{c}\text { Internal } \\
\text { and exter- } \\
\text { nal }\end{array}$ & $\begin{array}{c}\text { Transoral } \\
\text { robotic } \\
\text { surgery } \\
\text { (TORS) }\end{array}$ \\
\hline $\begin{array}{l}\text { Devesa P M et } \\
\text { al. [20] }\end{array}$ & 12 & $24-69$ & - & Yes & Yes & Non & Yes & Yes & - & $\begin{array}{l}\text { Internal } \\
\text { and } \\
\text { external }\end{array}$ & $\begin{array}{l}\text { Internaland } \\
\text { external }\end{array}$ & $\begin{array}{c}\text { Endoscopie } \\
\text { laser CO2 }\end{array}$ \\
\hline $\begin{array}{c}\text { Robert T et al. } \\
{[21]}\end{array}$ & 10 & $18-69$ & - & - & - & - & - & - & - & $\begin{array}{l}\text { Internal } \\
\text { and } \\
\text { external }\end{array}$ & $\begin{array}{l}\text { Internaland } \\
\text { external }\end{array}$ & $\begin{array}{l}\text { external } \\
\text { surgery }\end{array}$ \\
\hline Cisse N et al. & 2 & $0-35$ & no risk factor & Yes & Yes & No & Yes & Yes & Yes & & $\begin{array}{c}\text { Internal } \\
\text { and exter- } \\
\text { nal }\end{array}$ & $\begin{array}{l}\text { external } \\
\text { surgery }\end{array}$ \\
\hline
\end{tabular}




\section{Discussion}

Laryngocele is five to seven times common in humans with a peak around the sixth decade [9]. Laryngoceles are superinfected in $8 \%$ of laryngocele, hence the name of laryngopyocele [1012]. The etiology of the laryngocele is unclear, the hypothesis of congenital enlargement of the saccule as well as the acquired risk factors related to the increase in laryngeal pressure have been reported $[1,5]$. The cause is multifactorial, explained by the chronic pressure on the larynx found in wind instrument musicians, glass blowers and during laryngeal carcinoma $[1,5]$. The association of laryngocele with other pathologies such as amyloidosis, ankylosing spondylitis, also after a sub-maxillectomy for chronic sialadenitis, for salivary calculus as well as in the aftermath of a tracheostomy has been reported by the authors $[2,13,14]$. In our study, the congenital hypothesis was adopted before the juvenile age of the first patient, the absence of other risk factors and the existence of this mass since childhood in the second patient. It is unilateral in $85 \%$, bilateral in $15 \%$, external in $30 \%$, internal in $20 \%$ and combined in $50 \%[1,2,7,8]$.

Clinical and paraclinical investigations have highlighted in both cases the mixed laryngocele. It presents three anatomopathological forms:

a. Internal laryngocele: limited dilation in the endolarynx in the paraglottic region.

b. The external laryngocele translating an externalization of the dilation outside the larynx through the thyro-hyoid membrane

c. The mixed laryngocele combining the two entities $[1,4]$.

d. Laryngocele can be asymptomatic and accidentally discovered [15]. However, its symptomatology depends on the type of laryngocele:

e. The external, internal and mixed non-bulky types have a discreet symptomatology such as voice coil, pharyngeal discomfort, cough, dysphonia and discreet swelling from the angle of the mandible spontaneous or visible during a effort (coughing, screaming) $[9,14,15]$. The examination found an expansive swelling at the Valsalva maneuver and depressible to compression $[2,9,15]$. We noted in the first patient a nonexpansive mass during cries and not depressible on palpation, unlike in the second patient.

f. Nasofibroscopy and rigid endoscopy may be normal or objectified swelling of the ventricular band making more or less a mass effect on the glottic region $[9,14]$.

Signs of compression and / or obstruction, especially dyspnea that can lead to asphyxia, dysphagia and immediately visible laterocervical swelling are found in the external, internal and mixed giant types $[14,15]$. The examination finds in this case an obstruction of the glottal region, a painful swelling especially in case of superinfection (laryngopyocele) and incompressible in case of production of mucus (laryngomucocele) or pus [10-12,15,16]. Both of our patients presented with the laterocervical swelling as a primary symptom and signs of laryngeal compression (dysphonia) and laryngeal obstruction (dyspnea). Imaging reinforces the clinical presumption [2,17]. MRI would play a lesser role in the diagnosis of laryngocele. Tomodensitometry is the reference objectivate a well-circumscribed aerobic hypodensity communicating or not with the paraglottic region and an enhancement of the peripheral contrast product $[2,17]$. The tomodensitometric aspect in our two patients highlighted communication of the laryngocele with the ventricle. The anatomopathological result of the various operative specimens concluded a pseudotratified epithelium ciliated with goblet cells without signs of malignancy, which is also reported in the literature [1]. The differential diagnosis of laryngocele includes the sacral cyst, branchial cyst, thyroglossal canal cyst, neck abscess, lymphadenopathy, and laryngeal hemangioma $[2,4,18]$. Several types of laryngocele treatment are reported among others minimally invasive techniques: laser endoscopy, transoral robotic surgery (TORS). These techniques have less morbidity with a decrease in hospitalization time $[1,16,19,20]$. They remain reserved for isolated or mixed internal forms [1]. The external surgical approach is the traditional technique of choice [20,21]. Surgery offers better visibility of the external and mixed laryngocele $[20,21]$. Thyrotomy resects the internal laryngocele closest to the ventricle under visual control $[20,21]$. The external approach is possible with a minimum technical platform; but has the drawbacks of neck scarring, increased operative time, associated morbidity, the need for tracheostomy and prolonged hospitalization [20,21]. Our therapeutic alternative was an external approach without lateral thyrotomy. Our therapeutic alternative was encouraged by the absence of compression of laryngocele with less marked signs of laryngeal callus and the presence of laryngocele communication with the ventricle. Our cases were all free of tracheostomy and were released on two days after cervicotomy.

\section{Conclusion}

Laryngocele is a sacral dilatation of the laryngeal ventricle. It is rare in literature. Despite its unknown etiology, the congenital and acquired hypothesis remains valid. Swelling in the Valsalva expansive mandible isolated or associated with signs of compression and/ or compression remains a diagnostic argument for laryngocele. Externally excised laryngocele without conventional thyrotomy is a therapeutic alternative to noninfected mixed laryngocele, communicating with the ventricle without marked obstruction of the larynx. Since tracheostomy is unnecessary, the morbidity will be less.

\section{References}

1. Kara I, Kokoglu K, Cagli S, Yuce I (2019) Bilateral laryngocele causing epiglottic deformity and upper airway obstruction. Turk Arch Otorhinolaryngol 57(2): 99-101.

2. Swain SK, Chandra Mallik K, Mishra S, Chandra Sahu M (2015) Laryngocele: experience at a tertiary care hospital of eastern India Journal of Voice 29(4): 512-516. 
3. Gupta SC, Goel A, Singh PA (1998) External laryngocele. Indian Journal of Otolaryngology and Head \& Neck Surgery 50(3): 298-301.

4. Oukessou Y, Abada RL, Roubal M, Mahtar M (2015) Laryngocele: an unusual presentation. European Annals of Otorhinolaryngology, Head and Neck diseases 132(3): 177-178.

5. Zagkou E, Aldridge T, Alam P, Brennan PA (2016) Spontaneous rupture of an internal laryngocele after neck dissection: a rare complication. British Journal of Oral and Maxillofacial Surgery 54(10): 1128-1130.

6. Felix JA, Felix F, Mello LF (2008) Laryngocele: A cause of upper airway obstruction. Revista Brasileira de Otorrinolaringologia 74(1): 143-146.

7. Kishore Chandra Prasad, Vijayalakshmi S, Sampath Chandra Prasad (2008) Laryngoceles presentations and management. Indian Journal of Otolaryngology and Head \& Neck Surgery 60(4): 303-308.

8. Sun Yu Lam, Hin Yue Lau (2018) A rare case of Laryngopyocele with airway obstruction. The Journal of Clinical Imaging Science 8: 42.

9. Mobashir MK, Basha WM, Mohamed AE, Hassaan M, Anany AM (2017) Laryngoceles: concepts of diagnosis and management. ENT-Ear, Nose \& Throat Journal 96(3): 133-138.

10. Vishnu Vardhan Reddy M, Ramakrishna C, Manish Gupta, Shobhan Babu A, Shankar T, et al. (2008) Laryngocele - a case report and review of literature. Indian Journal of Otolaryngology and Head \& Neck Surgery 60(3): 281-283.

11. Upile T, Jerjes W, Sipaul F, El Maaytah M, Singh S, et al. (2006) Laryngocele: a rare complication of surgical tracheostomy. BMC Surgery 6: 14 .

12. Pennings RJ, Van Den Hoogen FJ, Marres HA (2001) Giant laryngoceles: a cause of upper airway obstruction Eur Arch Otorhinolaryngol 258: 137140.
13. Mehmet Ali Aslaner (2018) Laryngopyocele: A deep neck infection diagnosed by emergency ultrasound. Am J Emerg Med 36(11): 2132.e52132.e7.

14. Mohamed I T, Omer N, Adnan H, Omer M (2003) Laryngocele: a case report. JRMS 10(2): 54-57.

15.Zribi S, Harlga I, Zairi D, Hachicha A, Ben Amor M, et al. (2013) Laryngocele a propos de 9 cas. J Tun ORL janvier-juin 29: 16-19.

16. Villeneuve A, Vergez S, Bakhos D, Lescanne E, Pinlong E, et al. (2016) Management of laryngoceles by transoral robotic surgery. Eur Arch Otorhinolaryngol 273(11): 3813-3817.

17. Mahdoufi R, Barhmi I, Tazi N, Abada R, Roubal M, et al. (2017) Mixed pyolaryngocele: a rare case of deep neck infection. Iranian Journal of Otorhinolaryngology 29(93): 225-228.

18. Shaigany K, Ahmad SM, Jamal N (2017) Laryngeal hemangioma presenting as a laryngocele. ENT-Ear, Nose \& Throat Journal 96(10-11): 408-411.

19. Ciabatti PG, Burali G, D'Ascanio L (2013) Transoral robotic surgery for large mixed laryngocoele. The Journal of Laryngology \& Otology 127(4): 435-437.

20. Martinez Devesa P, Ghufoor K, Lloyd S, Howard D (2002) Endoscopic $\mathrm{CO}_{2}$ Laser Management of Laryngocele. Laryngoscope 112(8): 1426-1430.

21. Robert T, Daniela CT, Rodrigo ACD Cortina (2000) Lateral thyrotomy approach on the paraglottic space for laryngocele resection. The Laryngoscope 110(3 Pt 1): 447-450. 